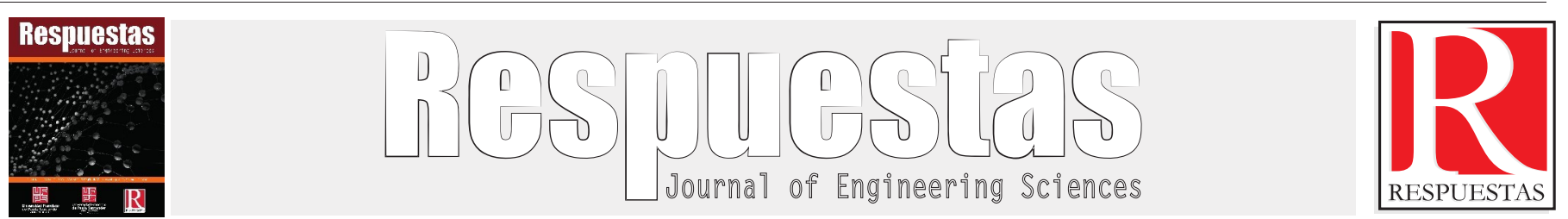

Original Article

https://doi.org/10.22463/0122820X.1794

\title{
Specific heat measurement of organic and conventional coffee samples by thermal relaxation
}

\author{
Medición del calor específico de muestras de café orgánico y convencional por relajación térmica \\ Fernando Gordillo-Delgado ${ }^{1 *}$, Diego Fernando Valencia-Grisales ${ }^{2}$, John Alexander García-Giraldo \\ ${ }^{1}$ Doctor en tecnología avanzada, fgordillo@uniquindio.edu.co, ORCID: 0000-0002-2940-1129, Universidad del Quindio, Armenia, Colombia. \\ ${ }^{2}$ Ingeniero electrónico, dfvalenciag@uqvirtual.edu.co, ORCID: 0000-0002-5555-9210, Universidad del Quindio, Armenia, Colombia. \\ ${ }^{3}$ Ingeniero electrónico, jagarciag_1@uqvirtual.edu.co, ORCID: 0000-0002-2628-7850, Universidad del Quindí, Armenia, Colombia.
}

How to cite: F. Gordillo-Delgado, D. Valencia-Grisales and J. García-Giraldo, "Specific heat measurement of organic and conventional coffee samples by thermal relaxation". Respuestas, vol. 24, no. 3, pp. 65-71, 2019.

Received on February 15, 2018 - Approved on June 25, 2018

\begin{tabular}{ll}
\hline ABSTRACT \\
\hline Keywords: & $\begin{array}{l}\text { The specific heat at constant pressure }(C p) \text { is a thermal parameter necessary to describe the heat } \\
\text { transport in a material, related to adaptation to changes of temperature, which is very important in the } \\
\text { evaluation and inspection of inputs for the construction, adhesives, thermal insulators and electronic } \\
\text { devices. In this work, a thermal relaxation system with infrared thermometry was used to determine the }\end{array}$ \\
$\begin{array}{l}C p \text { of green coffee beans, measuring the temperature of the material placed inside a vacuum } \\
\text { chamber that reaches a pressure of } 10^{-2} \text { Torr. The sample was heated by radiation with laser light } \\
\text { Specific heat, }\end{array}$ & $\begin{array}{l}\text { and the data was obtained by means of an acquisition card. The calibration of the system was } \\
\text { made comparing the } C p \text { values obtained for zinc, tungsten, titanium and steel with those reported } \\
\text { by other authors and similarity was found between both. This method was used to measure the } C p \text { of } \\
\text { criteria, }\end{array}$ \\
Instrumentation. & $\begin{array}{l}\text { samples of organic and conventional coffee; these values were subjected to an analysis of variance and } \\
\text { significant differences were found with a confidence level of } 95 \% \text {. This technique could be used for the } \\
\text { discrimination of organic coffee in a certification process. }\end{array}$
\end{tabular}

\section{RESUMEN}

Palabras clave:

El calor específico a presión constante $(C p)$ es un parámetro térmico necesario en la descripción del transporte de calor en un material, relacionado con la adaptación a cambios de temperatura, lo que

Café, es importante en la valoración e inspección de insumos para la construcción, pegantes, aislantes

Calor específico,

Criterio de térmicos y dispositivos electrónicos. En este trabajo se utilizó un sistema de relajación térmica con termometría infrarroja para determinar el $C p$ de granos de café verde, midiendo la temperatura del discriminación, Instrumentación. material colocado dentro de una cámara de vacío que alcanza una presión de $10^{-2}$ Torr. La muestra se calentó por radiación con luz láser y los datos fueron obtenidos mediante una tarjeta de adquisición. La calibración del sistema se hizo comparando los valores obtenidos de $C p$ de láminas de Zinc, Wolframio, Titanio y Acero con los reportados y se encontró similitud. Este método se usó para medir el $C p$ de muestras de café orgánico y convencional; estos valores se sometieron a un análisis de varianza y se hallaron diferencias significativas con un nivel de confianza del 95\%, lo que permite afirmar que la técnica podría ser utilizada para la discriminación de café orgánico en el proceso de certificación.

\section{Introduction}

The fundamentals of heat transfer were established by Fourier [1]. The thermal characteristics of solids determine their behavior under a temperature gradient [2], which is important in industry and material sciences. In particular, specific heat expresses the amount of heat dissipated in a unit volume sample when its temperature varies by one degree [3].

The development of simple systems for measuring this parameter is a matter of interest because of a commercial equipment as a differential scanning calorimeter is high cost and the analytical methods and calculations are restricted to initial conditions and temperature ranges; on the other hand, the thermal relaxation technique is one of the most simple and functional method [4], [5]. This 
method is based on the disturbance of the state of thermodynamic equilibrium by means of constant illumination of the sample suspended adiabatically, inside a vacuum chamber; the variation of the sample absolute temperature is measured as a function of time [6]. Infrared radiometry is often used to measure the temperature of the sample, taking into account the heat losses influence by convection and radiation. The analytical solution of the heat diffusion equation allows to obtain the $C p$ of the material through the analysis of the temperature evolution between two parallel surfaces of a solid sample [7]. In recent years, this method has been used for the thermal characterization of semiconductor materials, food, wood, zeolites, clays and polymers [3] and for developing discrimination criteria [8], because of the specific heat depends on the internal structure of a material and it is characteristic of each substance.

On the other hand, in organic coffee growing, the environmentally friendly practices bring this activity closer to being sustainable, because they give added value to the product [9]. However, the commercialization of this merchandise requires the intervention of certifying entities that inspect and guarantee the origin and denomination through a costly and lengthy process that is based on onsite inspection and testing on each farm. For this reason, the use of a quantitative method, such as the one that can be visualized from the results of this work, could support the discrimination of organic coffee through a precise measurement that is quick and low-cost and does not require sample preparation.

In this work, the thermal relaxation method was used to measure the $C p$ of organic and conventional coffee samples for differentiation purposes. The single factor analysis of variance (ANOVA) led to find a significant difference between the data of both types of coffee. In the implementation of the measurement system it was guaranteed that the sensed temperature was acquired and saved as a data in function of time, using programming and synchronization of the algorithms installed in the interfaces.

\section{Materials and methods}

\section{Coffee Samples}

Using the thermal relaxation technique, $C p$ measurements of coffee samples were taken in triplicate. 10 samples of both organic and conventional coffee were chosen at random from a corresponding set of coffee beans. The fruits of Castillo variety coffee plants (Coffea arabica) were collected in farms located in the municipality of Salento in the department of Quindío, at an altitude between 1721 and 1756 MSL. The mucilage was removed from the seeds by fermentation [10] during 24 hours and the seed was dried until reaching a moisture between 14.1 and $14.4 \%$, measured with a UNIMETER DIGITAL equipment. The coffee beans were transformed into layers with thickness between 0.6 and $0.75 \mathrm{~mm}$, by means of a transversal cut using a rotary microtome.

\section{Cp Measurement}

Figure 1 shows the general scheme of the assembly of the measuring system; the sample is heated by radiating its upper surface with a laser beam and the temperature gradient is measured as a function of time, using infrared thermometry. The sample was placed inside a vacuum enclosure, a cylindrical stainless steel chamber $400 \mathrm{~mm}$ high and $250 \mathrm{~mm}$ in diameter, until reaching a pressure around $10^{-2}$ Torr, using a Leybold Trivac D 2.5 E pump.

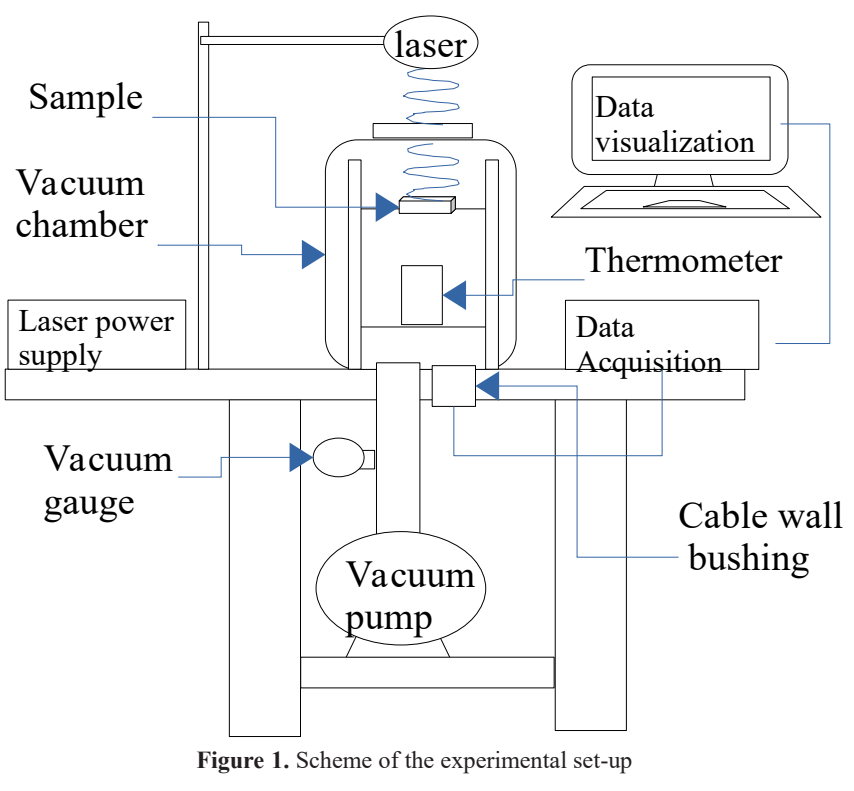


A personal computer was used to acquire the temperature that was measured with an infrared thermometer TM-908 LUTRON, which was pointed at the back of the sample. The data were recorded through a programmable development board, with a synchronized speed between receiving the temperature and sending information to the computer. This is crucial to avoid loss or information latency that would cause an erroneous taking of data.

The front surface of the samples (where the laser beam is focused) was dyed with a thin layer of carbon paint to ensure uniform heating and heat transfer. The light absorbed in the surface of the material is converted, in whole or in part, into heat because of non-radiative de-excitation processes. For a known heat source, namely $Q$, which radiates a sample of thickness $L$ and mass $m$, the temperature variation is measured as $\Delta T$.

Assuming that the sample is adiabatically suspended at atmospheric pressure, it is possible to write:

$$
Q=C \Delta T
$$

Where $C$ is the heat capacity, related to the specific heat as follows:

$$
C p=C / m \quad \text { (2) }
$$

The distribution of heat in a given region of the sample depends on the time of exposure to the heat source and it is expressed as:

$$
\partial Q / \partial t=P_{0}-P(3)
$$

Where $P o$ is the absorbed power of the incident radiation and $P$ symbolizes the losses of heat by conduction, convection and radiation. On the other hand, radiation, namely $R$, that represents energy losses is defined in the following equation:

$$
R=A \epsilon \sigma\left(T^{4}-T_{0}^{4}\right)
$$

Where $A$ is the sample surface area, $\epsilon$ is the emissivity, $\sigma$ the Stefan-Boltzmann constant and $T$ the absolute temperature, related to the room temperature at which the sample is found (thermal equilibrium). If the temperature variations, $\Delta T$, are near to the room temperature, it can be written as follows:

$$
T=T_{0}+\Delta T
$$

Where $T_{0}$ is the room temperature. In this way, the equation (4) can be reduced to:

$$
R=4 A \epsilon \sigma\left(T_{0}^{3} \Delta T\right)
$$

With regard to the convection, applying Newton's law of cooling (the loss of heat from a body is proportional to the difference in temperature between the body and its surroundings), it can be expressed as follows:

$$
d Q / d t=h A\left(T_{\text {sample }}-T_{\text {fluid }}\right)
$$

Where $h$ is the coefficient of convection that quantifies the influence of characteristics of the fluid (the air in the chamber), the surface and the heat flow when the transference occurs; therefore:

$$
Q=\rho c V \Delta T=C V \Delta T
$$

Where $\rho$ is the density and $V$ is the volume of the sample.

The differentiation of the equation (8) with respect to time and the substitution in the equation (3) drive to:

$$
\partial(\Delta T) / \partial t+(\beta / C) \Delta T-\left(P_{0} / C\right)=0
$$

Where, $\beta=A\left(4 \epsilon \sigma T_{0}^{3}+h\right)$.

With the initial condition $\Delta T(0)=0$, the solution to equation (9) is:

$$
\Delta T(t)=(P o / \beta)\left[1-\exp ^{(-t / \tau)}\right]
$$

Where, the thermal relaxation time, $\tau$, is given by:

$$
\tau=(L C / 2)\left(4 \in \sigma T_{0}^{3}+h\right)^{-1}
$$


When the heat source does not radiate the sample, the equation (10) changes, because of the temperature of the sample is saturated by a value $P_{0} / \beta$; therefore, the equation (12) is obtained when the temperature decreases:

$$
\Delta T(t)=P_{o} / \beta[\exp (-t / \tau)]
$$

When the sample is placed inside the chamber and the air is emptied into it, the heat transfer by convection tends to zero, so that the thermal relaxation time is mainly influenced by radiation phenomena and the parameter $h$ can be neglected; thus, $C$ can be calculated through equation (13).

$$
C=\left[8 \epsilon \sigma T_{0}^{3} \tau_{R}\right] / L
$$

\section{Results and Discussion}

In the Table I, the dimensions and mass of the sample layer, obtained by cuts of beans, are shown. It can be noted that the two kind of coffee are in the same range of size and weight.

Table I. Average size and mass of coffee samples (layers)

\begin{tabular}{|c|c|c|c|c|}
\hline sample & length $(\mathrm{mm})$ & wide $(\mathrm{mm})$ & thickness $(\mathrm{mm})$ & mass $(\mathrm{g})$ \\
\hline Conventional & $8,70 \pm 0,01$ & $5,87 \pm 0,01$ & $0,72 \pm 0,001$ & $0,0269 \pm 0,0001$ \\
\hline Organic & $7,63 \pm 0,01$ & $5,76 \pm 0,01$ & $0,66 \pm 0,001$ & $0,0220 \pm 0,0001$ \\
\hline
\end{tabular}

\section{Calibration of the thermal relaxation system}

Equations 10 and 12 describe respectively the evolution of the temperature of the heated sample by the laser and when it cools down to return to its initial temperature. From these expressions, the thermal relaxation time is obtained, which indicates how long it takes for the sample to reach its thermal equilibrium. For measurements in vacuum conditions, it is assumed that $\tau$ is equivalent to $\tau_{\mathrm{R}}$ (heat transfer only by radiation) and applying equation 13 the value of $C$ and $C p$ is calculated, considering the mass and volume of the samples, shown in Table II.

Parameter $\tau_{R}$ was found from the temperature evolution measurements in vacuum for zinc, tungsten, titanium and steel samples, as a function of time, during the heating and cooling process (when the sample is not irradiated).
The curves are shown in Figures $2 a$ ) and 2b), respectively.

Table II. Dimensions of the zinc, tungsten, titanium and steel samples.

\begin{tabular}{|c|c|c|c|c|}
\hline Samples & Long $(\mathrm{mm})$ & Wide $(\mathrm{mm})$ & Thickness $(\mathrm{mm})$ & Mass $(\mathrm{g})$ \\
\hline Zinc $99 \%(\mathrm{Zn})$ & $14,16 \pm 0,01$ & $14,15 \pm 0,01$ & $0,71 \pm 0,001$ & $0,94 \pm 0,0001$ \\
\hline Wolframe 99\%(W) & $15,00 \pm 0,01$ & $15,56 \pm 0,01$ & $0,96 \pm 0,001$ & $3,70 \pm 0,0001$ \\
\hline Titanium 99\%(Ti) & $20,08 \pm 0,01$ & $20,52 \pm 0,01$ & $1,03 \pm 0,001$ & $1,86 \pm 0,0001$ \\
\hline steel 99\% & $19,72 \pm 0,01$ & $18,7 \pm 0,01$ & $0,81 \pm 0,001$ & $2,34 \pm 0,0001$ \\
\hline
\end{tabular}
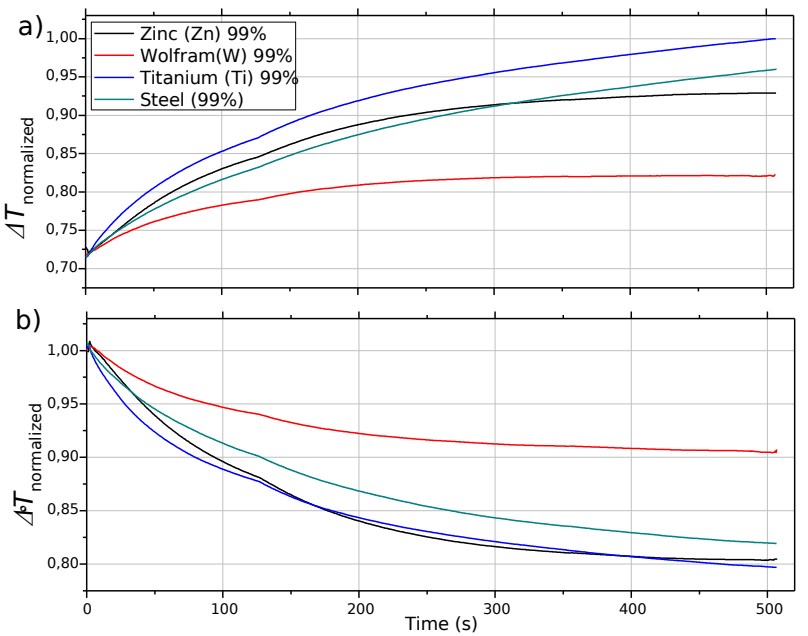

Figure 2. Evolution of temperature, normalized with the maximum value, corresponding to samples of zinc, tungsten, titanium and steel with $99 \%$ purity, taken in vacuum under a) incidence and b) without incidence of laser light.

The relaxation time was estimated as a fitting parameter to equations (10) and (12) and results are presented in Table III.

Table III. Obtained results of $C p$, through the thermal relaxation technique and values reported by other authors

\begin{tabular}{|c|c|c|}
\hline Samples & $C p$ measured $\left(\mathrm{J} \mathrm{g} \mathrm{K}^{-1}\right)$ & $C p$ reported $\left(\mathrm{J} \mathrm{g}^{-1} \mathrm{~K}^{-1}\right)$ \\
\hline Zinc 99\% $(\mathrm{Zn})$ & $0,384 \pm 0,005$ & $0,389[11]$ \\
\hline Wolfram $99 \%(\mathrm{~W})$ & $0,11 \pm 0,02$ & $0,133[12]$ \\
\hline Titanium 99\% (Ti) & $0,56 \pm 0,01$ & $0,543[13]$ \\
\hline steel 99\% & $0,46 \pm 0,01$ & $0,460[14]$ \\
\hline
\end{tabular}

\section{Cp measurement of organic and conventional coffee}

The $C p$ of ten samples of each type of coffee was determined with the thermal relaxation technique. Figures $3 a$ ) and $3 b$ ) show the evolution of temperature as a function of time, with and without incidence of laser light, respectively. The curves correspond to a sample of conventional coffee and one of organic coffee, but this behavior was similar in all cases. 

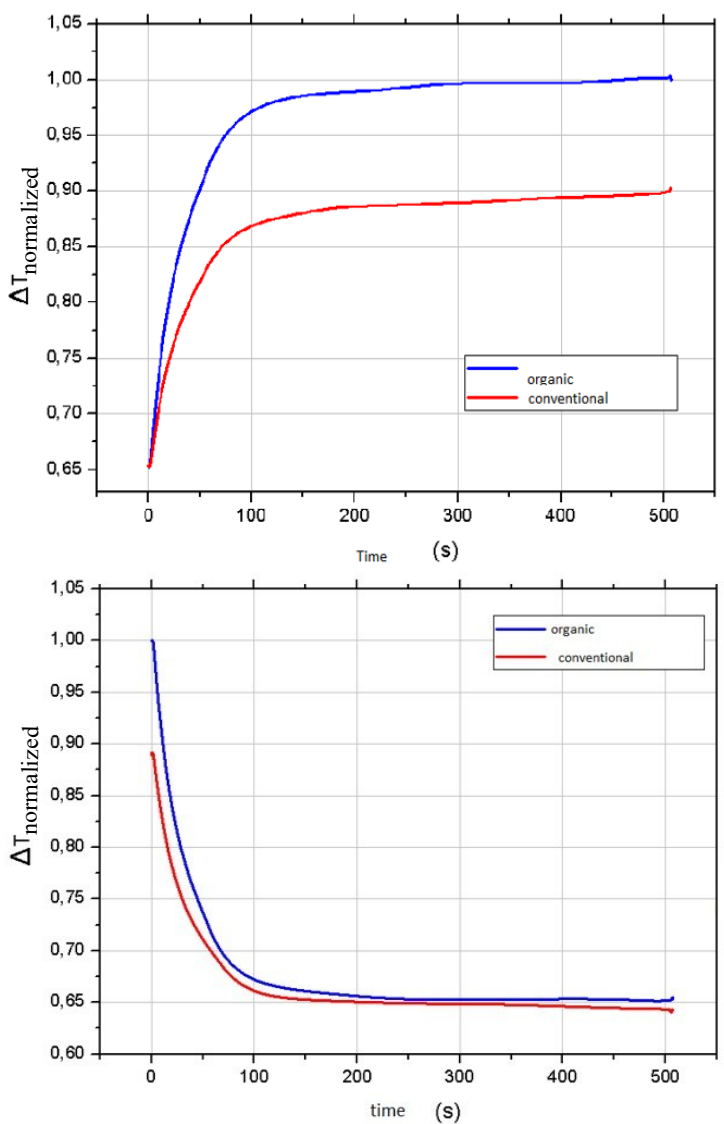

Figure 3. Behavior of temperature, normalized with the maximum value, corresponding to samples of organic and conventional coffee, taken in vacuum under a) incidence and b) without incidence of laser light.

\section{Application of single factor ANOVA}

A single factor analysis of variance (ANOVA) was applied to $C p$ data. The results ares shown in Table IV.

The values of $C p$ and $C$ of 10 samples of each kind of coffee beans were analyzed. In Table $\mathrm{IV}$, the average values obtained with their respective standard deviation and coefficient of variation are shown. The coefficient of variation for both beans classes is very low, which is associated to the precision of the measuring instrument and the data homogeneity. The average $C p$ value of the conventional and organic coffee samples was $1,32 \pm 0,03$ and $1,16 \pm 0,03 \quad \mathrm{~J}^{-1} \quad \mathrm{~K}-1$, respectively.
Table IV. Results of the $C p$ ANOVA of the coffee samples.

\begin{tabular}{|c|c|c|c|c|}
\hline Kind of coffee & Recount & $\begin{array}{c}\text { Average } \\
\left(\mathrm{J} \mathrm{g} \mathrm{g}^{-1}\right)\end{array}$ & $\begin{array}{c}\text { Standard } \\
\text { deviation } \\
\left(\mathrm{J} \mathrm{g}^{-1} \mathrm{~K}^{-1}\right)\end{array}$ & $\begin{array}{c}\text { Coefficient } \\
\text { of variation }\end{array}$ \\
\hline Conventional & 10 & 1,32 & 0,01 & $0,99 \%$ \\
\hline Organic & 10 & 1,16 & 0,01 & $1,28 \%$ \\
\hline Total & 20 & 1,24 & 0,08 & $6,85 \%$ \\
\hline
\end{tabular}

The ANOVA of one factor compares means; therefore to determine the discrimination potential of the $C p$ parameter, a null hypothesis $H_{o}$ and an alternative hypothesis $H_{A}$ were raised.

$$
H_{o}: C p_{\text {conventional }}=C p_{\text {organic }}=C p
$$

The null hypothesis defines that mean of $C p$ of the coffee samples, $C p_{\text {conventional and } C p_{\text {organic }}}$ (conventional and organic) are equal; whereas the alternative hypothesis, $H_{A}$, defined in (16), specifies that the value of the parameter $C p$ is different in both cases.

$$
H_{A}: C p_{\text {conventional }} \neq C p_{\text {organic }} \neq C p
$$

Table V. ANOVA applied to the $C p$ of coffee samples

\begin{tabular}{|c|c|c|c|c|c|}
\hline Source & $\begin{array}{c}\text { Sum of } \\
\text { squares } \\
\left(\mathrm{J} \mathrm{g}^{-1} \mathrm{~K}^{-1}\right)\end{array}$ & $\begin{array}{c}\text { Levels of } \\
\text { freedom }\end{array}$ & $\begin{array}{c}\text { Mean square } \\
\left(\mathrm{J} \mathrm{g}^{-1} \mathrm{~K}^{-1}\right)\end{array}$ & Reason-F & Value-P \\
\hline $\begin{array}{c}\text { Growing } \\
\text { method }\end{array}$ & 0,133188 & 1 & 0,133188 & 683,72 & 0,0000 \\
\hline Error & 0,003506 & 18 & 0,0001947 & & \\
\hline Total & 0,136694 & 19 & & & \\
\hline
\end{tabular}

Table V shows the ANOVA data; the total variation of the 20 analyzed data was 0.136694 $\mathrm{Jg}^{-1} \mathrm{~K}^{-1}$. Weighing these values with the corresponding degrees of freedom, the mean squares that reflect the real magnitude of each source of variation was obtained. It is noted that the difference due to the growing mode is 0.133188 $\mathrm{J} \mathrm{g}^{-1} \mathrm{~K}^{-1}$ and that the error is $0.0001947 \mathrm{~J} \mathrm{~g}^{-1} \mathrm{~K}^{-1}$; therefore, the mean square of the culture mode is approximately 683.72 greater than the mean square of the error; this indicates that the differences observed between both types of coffee growing are significant and are not due to small variations in the samples.

As the $\mathrm{P}$ value is less than $5 \%$, the null hypothesis is rejected and it is concluded that there is no equality between the means for each growing technique. 
The presence of significant differences between the $C p$ means of the samples of both types of crops was probed using the method of significant difference (LSD).

Table VI. Values from the application of the LSD test according to the growing technique of coffee

\begin{tabular}{|c|c|c|c|}
\hline Contrast & Sig. & Variance & +/- Limits \\
\hline $\begin{array}{c}\text { Conventional } \\
\text { Vs. organic } \\
\text { coffee }\end{array}$ & $*$ & 0,16321 & 0,0131135 \\
\hline
\end{tabular}

In Table VI the data from the LSD test are shown, from which it is determined that the means are significantly different with $95 \%$ confidence level.

\section{Conclusions}

The $C_{p}$ value of zinc, tungsten, titanium and steel samples, measured with the thermal relaxation system, was near to that reported by other authors. This establishes the reliability of the method.

The ANOVA applied to the $C p$ data, obtained through the thermal relaxation technique, allowed to establish a difference between samples of organic and conventional coffee. This single factor analysis, in which the response variable was the value of this parameter, led to define that this magnitude ranged between 1.3165 and $1.3233 \mathrm{Jg}^{-1} \mathrm{~K}^{-1}$ and between 1.1538 and $1.1596 \mathrm{Jg}^{-1} \mathrm{~K}^{-1}$, for conventional and organic coffee beans, respectively. On the other hand, information was obtained on the precision of the measurements, which had a coefficient of variation of less than $1 \%$.

Conventional coffee $C p$ is higher that organic coffee $C p$, it could be due to the different content of lipids, proteins and acids in both kind of coffee [15].

The electronic instrumentation was implemented to low cost and easy components acquisition, which gives added value to the development of the $C p$ measurement system as a viable option for the purpose of supporting the organic coffee certification process.

\section{Acknowledgements}

The authors thank the University of Quindío for funding this work, through project 924 and the support of the Instituto Interdisciplinario de las Ciencias de la Facultad de Ciencias Básicas y Tecnologías.

\section{References}

[1] J. B. Four, "Analytical theory of Heat (Encyclopedia Britannica, Inc.: Chicago)", 1952.

[2] N. L. Bernal, "Método De Calentamiento Transitorio Para La Caracterización Térmica De Sólidos", 2013.

[3] E. Marín, O. Delgado-Vasallo and H. Valiente, "A temperature relaxation method for the measurement of the specific heat of solids at room temperature in student laboratories", American Journal of Physics, vol. 71, no. 10, pp. 1032-1036, 2003.

[4] L. A. Ratamero, N. Cella and A. J. S. Neto, "An inverse problem for thermal diffusivity estimation with the photoacoustic spectroscopy", Journal of Physics: Conference Series, vol. 135, no. 1, pp. 012086, 2008.

[5] S. B. Luo, W. L. Wang, J. Chang, Z. C. Xia and B. Wei, "Specific heat capacity of liquid and solid Ni83.5Ti16.5eutectic alloy", Chemical Physics Letters, vol. 679, pp. 172-175, 2017.

[6] A. Lara-Bernal, E. Marín and A. Calderón, "Técnica de relajación térmica con excitación variable: Caso de la 'rampa' de intensidad", Superficies y vacío, vol. 20, no. 3, pp. 17-20, 2007.

[7] S. S. Gonçalves, M. da Silva, M. Sthel, S. Cardoso, R. Sanchez, J. Rieumont and H. Vargas, "No Title", Physica Status Solidi (a), vol. 187, 2001. 
[8] J. R. Satti, D. K. Das and D. Ray, "Specific heat measurements of five different propylene glycol based nanofluids and development of a new correlation", International Journal of Heat and Mass Transfer, vol. 94, pp. 343-353, 2016.

[9] F. Gordillo-delgado, F. Valencia-grisales and J. Plazas-saldaña, "uso de la técnica de alambre caliente para la medición de la conductividad térmica de infusiones de café orgánico y convencional", Revista de la Facultad de Ciencias de la Universidad Nacional de Colombia, Sede Medellín, vol. 5, pp. 105-113, 2016.

[10] Aguilar-Rivera, E. Houbron, E. Rustrian and L. C. Reyes-Alvarad, "Papel amate de pulpa de café (Coffea arabica) (Residuo de beneficio humedo)", Ra Ximhai, vol. 10, no. 3, pp. 103117, 2014.

[11] G. Seidel and P. H. Keesom, "Specific Heat of Gallium and Zinc in the Norxrial and Suyerconducting States", Physical Review, vol. 12, no. 4, pp. 1083-1088, 1958.

[12] M. M. Yakunkin, "Mechanism of High-Temperature Heat Capacity of Tungsten : Study of Relaxation Processes", Physics of the Solid State, vol. 46, no. 2, pp. 219-225, 2004.

[13] J. M. Gonzáles "Producción de peliculas de nitruro-titanio-aluminio- vanadio (TiALV) $\mathrm{N}$ variando la temperatura del sustrato por la tecnica PAPVD”, Universidad Nacional De Colombia, 2007.

[14] F. Incropera and D. Dewitt, "Fundamentos de transferencia de calor", Cuarta. Mexico, 1999.

[15] A. P. Macías-Martínez and C. E. Riaño-luna, "Café orgánico: caracterización, torrefacción y enfriamiento", Cenicafé, vol. 53, no. 4, pp. 281-292, 2002. 